\title{
Utilization of Blockchain Technology for Management E-Certificate Open Journal System
}

\author{
Farida Agustin ${ }^{1}$, Qurotul Aini ${ }^{2}$, Alfiah Khoirunisa ${ }^{3}$ Efa Ayu Nabila ${ }^{4}$ \\ STIE AI-Khairiyah ${ }^{1}$ Universitas Raharja ${ }^{234}$ \\ JI. K.H. Ahmad Dahlan No.15, Citangkil, Kec. Citangkil, Kota Cilegon, Banten 42441' ${ }^{1}$, Jl. \\ Jenderal Sudirman No.40, RT.002/RW.006, Cikokol, Kec. Tangerang, Kota Tangerang, \\ Banten $15117^{234}$ \\ agustin.farida71@gmail.com, aini@raharia.info, alfiah@raharia.info, efaayunabila@raharia.info
}

To cite this document :

Agustin, F., Aini, Q., Khoirunisa, A., \& Nabila, E.(2020). Utilization of Blockchain Technology for Management E-Certificate Open Journal System. Aptisi Transactions on Management (ATM), 4(2), 134139.

DOI :

https://doi.org/10.33050/atm.v4i2.1293

\begin{abstract}
The application of blockchain technology in e-certificates in the open journal system is needed to validate and distribute managed e-certificates in each journal issue. With tools in the form of conceptualized and managed blockcerts allows users to use and verify the authenticity of ecertificates that are closely linked to the blockchain. Observation on the open journal system and applied blockchain tools in the form of blockcerts as a place to issue e-certificates with guaranteed security so that e-certificates are verified as well as managed data. Issuance of e-certificates is still considered unsafe because it can be easily forged. Specifically, this study produced two benefits, namely: (1) Issuance of e-certificates in an open journal system is more verified, data is managed and there will not be duplications or even falsification of e-certificates. (2) The reputation of the open journal system is better with a sense of trust. This research uses library study method by implementing e-certificate in an open journal system with blockchain technology tools such as blockcerts. In order that the results of the e-certificate issuance go well and to avoid any crime that threatens the authenticity of the e-certificate, this blockchain is used to guarantee that the ecertificate is safe and not easily falsified, duplicated or even easily replaced by those not granted access rights. By using blockchain technology, the data collected will be well managed and not easily falsified.
\end{abstract}

Keywords: e-certificate, blockcerts, open journal system, management

\section{Introduction}

When first introduced by Satoshi Nakamoto, blockchain was known as the basic technology of the digital currency Bitcoin [1]. Blockchain is becoming increasingly popular and is applied in various fields besides monetary fields, such as online banks, e-commerce, smart city 
technology, health technology, and making digital certificates [2] [3] [4] [5] [6]. Activities with this technology are carried out every day and require security. In order to run smoothly and maintain privacy, messages sent when using various technologies can be encrypted with the private key of the sender [7]. So that users do not need to worry about the privacy of the data provided when using the application [8].

Social media provides space for individuals to share ideas and interests [9]. The number of sites or systems that are centralized also makes it easy for hackers to break into data because it only paralyzes one data center. Various problems regarding data can be overcome by using the latest blockchain technology on data distribution, network-shaped systems and having their own transcripts is very difficult to be disabled [10][11]. Also with a different transcript each block, it will not be possible for server users to duplicate and falsify data. By using blockchain technology, the data collected will be well managed and not easily falsified.

\section{Research Method}

The method is generally defined as the process, method, or procedure used to solve a problem. The method used to collect data in this study is as follows:

\subsection{Waterfall method}

The research method applied in this study is to use the development of the waterfall method. The waterfall method is a systematic and sequential information system development model [12]. The Waterfall method has the following stages [13]:

1) Requirements analysis and definition

The system services, constraints, and objectives of this study are determined by the results of consultations with users of the Open Journal System which are then defined in detail and serve as system specifications for the use of the blockchain [14].

2) System and software design

The stages of designing a blockchain system allocate OJS needs in the form of softcopy to form a blockchain system as a whole. Software design involves identifying and describing the abstraction of the basic blockchain system software and its relationship [15].

3) Implementation and unit testing

At this stage, software design is realized as a series of programs or program units. The test involves verifying the e-certificate that each page meets its specifications [16].

4) Integration and system testing

The e-certificate units are combined and tested as a complete system to ensure whether the ecertificate is suitable for the needs of OJS users. After testing, software can be sent to the author [17].

5) Operation and maintenance

This stage is the longest stage in the blockchain. The system is installed and used significantly. Maintenance in the form of rectification of errors that were not found in the previous stages, increasing the implementation of the system unit blockcerts, and improving system services as new requirements [18]. 


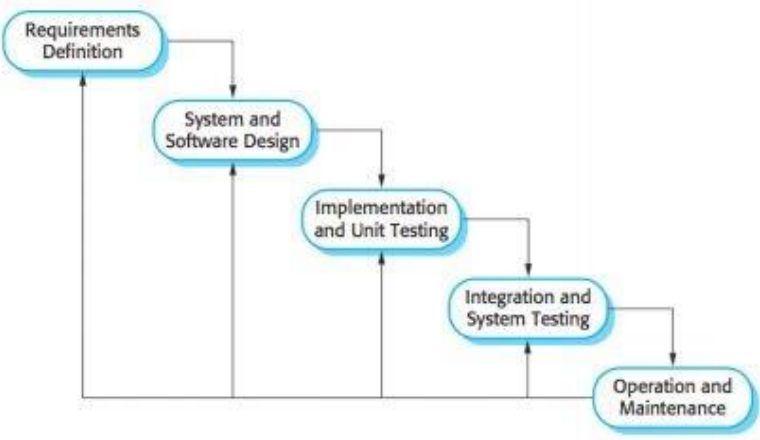

Fig. 1 Waterfall method

Figure 2 is a chart of the waterfall method which is a system development method used in this study [19].

\section{Results and Analysis}

\subsection{Problem Analysis}

Changes that occur in the world of education today are so significant with the commencement of the abandonment of teaching methods that still use conventional methods [20]. Based on the current problems, the issuance and storage of e-certificates in the open journal system do not have high security, so it is not efficient in utilizing technological advancements and still has not received full trust from its users [21]. To improve the performance of the open journal system in disseminating information, we need a system to overcome this. [22]

\subsection{Utilization of Blockchain Technology for Issuance of E-certificates}

The application of blockchain technology in e-certificates in the open journal system is needed to validate and distribute managed e-certificates in each journal issue. Blockchain technology will continue to evolve, so to face the development and efficiency of existing technology use blockchain tools in the form of blockcerts containing transcripts for e-certificate issuance. Like when making a transaction, an error can occur that if not resolved immediately will cause problems [23].

\subsection{Problem Resolution}

One technique to overcome the problem of user trust related to e-certificates and overcome data falsification is to provide a distinction between documents, in the form of transcripts on blockchain technology [24]. By utilizing blockcerts, certificates issued will be verified. The e-certificate in http://att.aptisi.or.id/ aims to give appreciation to the author so that the writer feels his work has been appreciated. E-certificates that have been issued will contain a very unique transcript that functions as the owner's e-certificate key and contains a signature. That way, owners who want to determine their decision to use e-certificate services in the future can be identified through the values perceived by the owner at the time of publication [25].

\subsection{Implementation}

To realize this system, an open public sub-menu was created in the APTISI Transactions on Technopreneurship (ATT Journal) system in the form of e-certificates.

1. Display Home on APTISI Transactions on Technopreneurship (ATT Journal) 


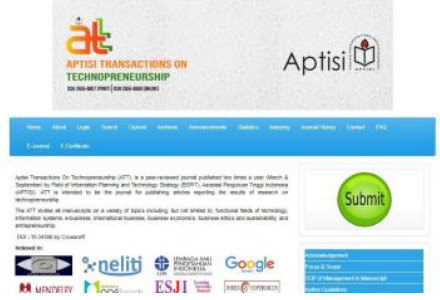

Picture 1.Home in ATT Journal.

The picture above is the home display on the ATT Journal, the first appearance that appears when accessing the website: att.aptisi.or.id/. A dynamic home display with banners showing projects developed by Raharja personally.

2. Display of E-Certificate in APTISI Transactions on Technopreneurship (ATT Journal)

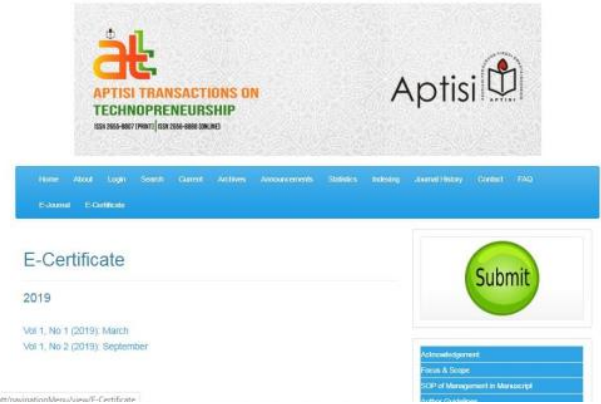

Picture 2. E-certificate menu in APTISI Transactions on Technopreneurship (ATT Journal)

3. E-certificate that has been published in APTISI Transactions on Technopreneurship (ATT Journal)

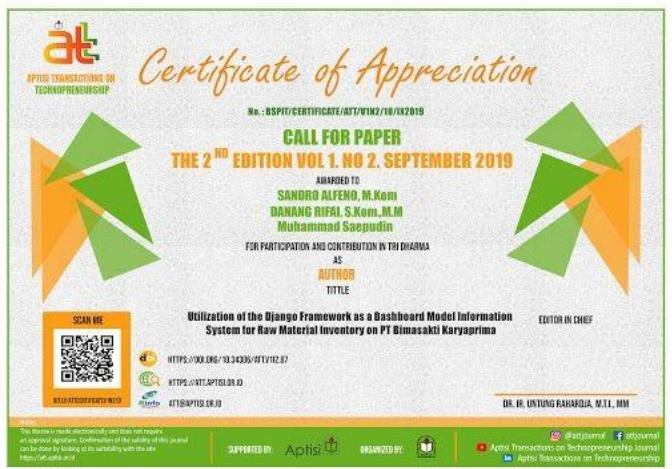

Picture 3.Display e-certificate in APTISI Transactions on Technopreneurship (ATT Journal)

The picture above is an e-certificate display on the ATT Journal accompanied by an encryption code that was used at the time of publication.

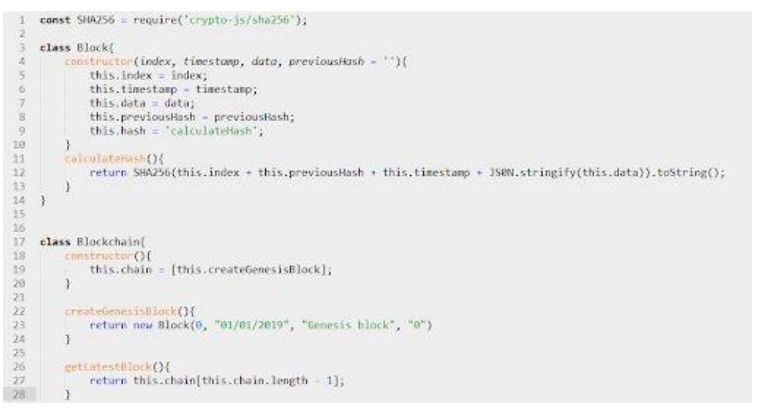

Picture 4. Display blockcerts script on e-certificate open journal system 


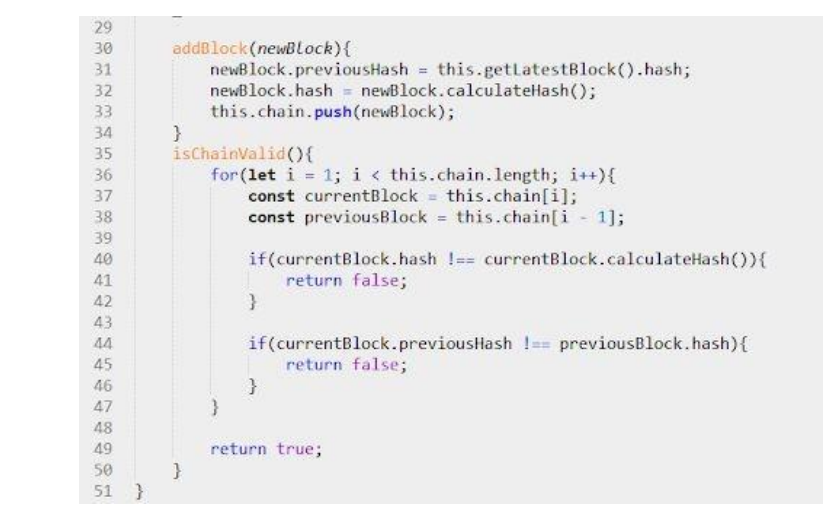

Picture 5. Display blockcerts script on e-certificate open journal system

\section{Conclusion}

With the implementation of the e-certificate feature in the APTISI Transactions on Technopreneurship (ATT Journal) system, 2 (two) conclusions can be drawn as follows:

1. The e-certificate feature enhances the author's enthusiasm to publish a journal in APTISI Transactions on Technopreneurship (ATT Journal)

2. The application of the blockcerts to the e-certificate feature makes certificates issued authenticated and cannot be duplicated.

\section{References}

[1] Nakamoto, (2008) "Bitcoin: a peer-to-peer electronic cash system," [Online], http//w ww.bitcoin.org/bitcoin.pdf, access date: 23 Sept. 2019.

[2] Brambilla, "Peer-to-Peer Location-Based Services based on Blockchain and Web Technologies," Disertasi, Università degli Studi di Parma, Parma, Italia, Des. 2017.

[3] Wilkinson dan J. Lowry, "MetaDisk: Blockchain-Based Decentralized File Storage Application," Storj Labs Inc., Technical Report, hal. 1-11, 2014.

[4] Ibba, A. Pinna, M. Seu, dan F.E. Pani, "CitySense," Proc. XP2017 Sci. Work. - XP '17, 2017, hal. 1-5.

[5] X. Yue, H. Wang, D. Jin, M. Li, dan W. Jiang, "Healthcare Data Gateways: Found Healthcare Intelligence on Blockchain with Novel Privacy Risk Control," J. Med. Syst., Vol. 40, No. 10, hal. 1-8, Oct. 2016.

[6] Rahardja, U., Hariguna, T., \& Baihaqi, W.M.(2019). OPINION MINING ON E-COMMERCE DATA USING SENTIMENT ANALYSIS AND K-MEDOID CLUSTERING. 2019 Twelfth International Conference on Ubi-Media Computing (Ubi-Media), 168-170.

[7] Prado, N. F., \& Henriques, M. A. (2018, October). On-block certs: blockchain-based lightweight digital certificates. In Anais Estendidos do XVIII Simpósio Brasileiro em Segurança da Informação e de Sistemas Computacionais (pp. 177-180). SBC.

[8] Zyskind, G., \& Nathan, O. (2015, May). Decentralizing privacy: Using blockchain to protect personal data. In 2015 IEEE Security and Privacy Workshops (pp. 180-184). IEEE.

[9] Hariguna, T., Rahardja, U., Aini, Q., \& Nurfaizah.(2019). Effect of social media activities to determinants public participate intention of e-government. The Fifth Information Systems International Conference 2019, 1-8.

[10] Putra, G. D., Sumaryono, S., \& Widyawan, W. (2018). Rancang Bangun Identity and Access Management loT Berbasis KSI dan Permissioned Blockchain. Jurnal Nasional Teknik Elektro dan Teknologi Informasi, 7(4), 384-390.

[11] Harahap, E. P., Aini, Q., \& Anam, R. K. (2020). PEMANFAATAN TEKNOLOGI BLOCKCHAIN PADA PLATFORM CROWDFUNDING. Technomedia Journal, 4(2), 199-210. 
[12] Pressman, R.S. 2002. Rekayasa Perangkat Lunak: Pendekatan Praktisi(Buku Dua). Yogyakarta: Penerbit Andi.

[13] Sommerville, I. (2011). Software Engineering 9th Edition. Addison-Wesley.

[14] Ross, D. T., \& Schoman, K. E. (1977). Structured analysis for requirements definition. IEEE transactions on Software Engineering, (1), 6-15.

[15] Bharthulwar, S. V. (2018). U.S. Patent No. 10,001,975. Washington, DC: U.S. Patent and Trademark Office.

[16] Sudrajat, D., Achdisty, M., Kurniasih, N., Mulyati, S., Purnomo, A., \& Sallu, S. (2019, December). The Implementation of Innovation in Educational Technology to Improve The Quality of Website Learning in Industrial Revolution Era 4.0 Using Waterfall Method. In Journal of Physics: Conference Series (Vol. 1364, No. 1, p. 012044). IOP Publishing.

[17] Lucitasari, D. R., \& Khannan, M. S. A. (2019). Designing Mobile Alumni Tracer Study System Using Waterfall Method: an Android Based. International Journal of Computer Networks and Communications Security, 7(9), 196-202.

[18]. Kramer, M. (2018). Best practices in systems development lifecycle: An analyses based on the waterfall model. Review of Business \& Finance Studies, 9(1), 77-84.

[19] Sasmito, G. W. (2017). Penerapan Metode Waterfall Pada Desain Sistem Informasi Geografis Industri Kabupaten Tegal. Jurnal Informatika: Jurnal Pengembangan IT, 2(1), 612.

[20] Wang, W., Hoang, D. T., Hu, P., Xiong, Z., Niyato, D., Wang, P., ... \& Kim, D. I. (2019). A survey on consensus mechanisms and mining strategy management in blockchain networks. IEEE Access, 7, 22328-22370.

[21] Rahardja, U., Aini, Q., Graha, Y. I., \& Khoirunisa, A. (2019, May). Implementation of Gamification into Management of Education for Motivating Learners. In Proceeding Interuniversity Forum for Strengthening Academic Competency (Vol. 1, No. 1, pp. 209-209).

[22] Chuat, L., Abdou, A., Sasse, R., Sprenger, C., Basin, D., \& Perrig, A. (2019). Proxy Certificates: The Missing Link in the Web's Chain of Trust. arXiv preprint arXiv:1906.10775.

[23] Rahardja, U., \& Harahap, E. P. (2019, July). Implementation Of Information Planning and Strategies Industrial Technology 4.0 to Improve Business Intelligence Performance on Official Site APTISI. In Journal of Physics: Conference Series (Vol. 1179, No. 1, p. 012111). IOP Publishing.

[24] Rahardja, U., Hariguna, T., \& Baihaqi, W.M.(2019). OPINION MINING ON E-COMMERCE DATA USING SENTIMENT ANALYSIS AND K-MEDOID CLUSTERING. 2019 Twelfth International Conference on Ubi-Media Computing (Ubi-Media), 168-170.

[25] Aini, Q., Simbolon, R., \& Dewi, S. R. (2019). Effects of Credit Memos on Performance Accountant on Uncollectible Receivables. Aptisi Transactions on Management (ATM), 3(2), 149-158. 